\title{
Prednisolone and cefapirin act synergistically in resolving experimental Escherichia coli mastitis
}

\author{
Anja Sipka, ${ }^{* 1}$ Abhijit Gurjar, ${ }^{*}$ Suzanne Klaessig, ${ }^{*}$ Gerald E. Duhamel, $†$ Andrew Skidmore, $\ddagger$ Jantijn Swinkels,‡ \\ Peter Cox,§ and Ynte Schukken* \\ *Department of Population Medicine and Diagnostic Sciences, and \\ †Department of Biomedical Sciences, College of Veterinary Medicine, Cornell University, Ithaca, NY 14853 \\ ¥Merck Animal Health, Global Ruminants Business Unit, Summit, NJ 07901 \\ §MSD Animal Health Innovation, 49070 Beaucouzé, France
}

\begin{abstract}
Mastitis in dairy cows is typically treated with intramammary antibiotics. The combination of antibiotics with corticosteroids tends to have a large market share where these products are registered. Our objective was to investigate the effect of prednisolone in combination with cefapirin on the inflammatory response of experimentally induced Escherichia coli mastitis. Six midlactating Holstein-Friesian cows were challenged in 3 quarters with E. coli and treated at 4, 12, 24, and $36 \mathrm{~h}$ postinfection with $300 \mathrm{mg}$ of cefapirin in 1 quarter and a combination of $300 \mathrm{mg}$ of cefapirin and $20 \mathrm{mg}$ of prednisolone in another quarter. At $24 \mathrm{~h}(\mathrm{n}=3)$ or $48 \mathrm{~h}(\mathrm{n}=3)$ postinfection cows were euthanized for tissue sampling. Clinical scores, somatic cell count, and California mastitis test scores, as well as IL-1 $\beta$, IFN- $\gamma$, IL-4, and IL-10 levels and bacterial growth in milk, were measured every $6 \mathrm{~h}$. Experimental inoculation caused a moderate clinical mastitis in all cows in challenged, untreated quarters. The E. coli challenge strain was recovered from all infected quarters and confirmed by PCR-based fingerprinting. Challenged, untreated control quarters showed increased concentrations of all measured cytokines together with recruitment of polymorphonuclear neutrophilic leukocytes at 24 and $48 \mathrm{~h}$ postchallenge. Both treatments reduced udder swelling and sensitivity with no statistically significant difference between treatment groups. Administration of cefapirin alone or in combination with prednisolone resulted in significantly lower concentrations of IFN- $\gamma$, IL-1 $\beta$, and IL-10 compared with challenged, untreated quarters. Treated quarters did show IL-4 production, but concentrations were significantly decreased compared with untreated, challenged quarters. Quarters treated with the combination of cefapirin and prednisolone showed a significantly lower concentration of IL-4 compared with
\end{abstract}

Received December 5, 2012.

Accepted April 2, 2013.

${ }^{1}$ Corresponding author: ass233@cornell.edu cefapirin-only treatment. At both 24 and $48 \mathrm{~h}$ postinoculation, the level of polymorphonuclear neutrophilic leukocyte recruitment was lowest in challenged quarters treated with a combination of cefapirin and prednisolone, followed by cefapirin alone. Taken together, treatment with cefapirin alone inhibited bacterial growth in milk and reduced the host inflammatory responses. Addition of prednisolone to cefapirin had a synergistic effect, resulting in a lower density of leukocytes in tissue and milk and a quicker restoration of milk quality. Key words: Escherichia coli mastitis, corticosteroid, inflammatory response

\section{INTRODUCTION}

Intramammary infections are known to be a major concern in the dairy industry due to severe milk loss, considerable treatment costs, and potentially fatal outcome. Among gram-negative bacteria, Escherichia coli is the most important and best characterized pathogen (Schukken et al., 2011b). Most severe cases of E. coli mastitis occur around parturition and in early lactation in high-yielding dairy cows. They often go along with severe clinical symptoms, such as damage of udder tissue, high fever, loss in appetite, and general depression of the animal, and the most severe cases can lead to the death of the cow (Burvenich et al., 2003). To date, several treatment recommendations for E. coli mastitis exist. The use of antimicrobials is ambiguously discussed. Some studies show no beneficial effects of antimicrobial treatment in lactating cows and therefore recommend not treating mild to moderate cases due to the usually short duration and self-limiting character of the inflammation (Pyörälä et al., 1994; Suojala et al., 2010). The guidelines for antimicrobial use in cattle (Constable et al., 2009) recommend no antimicrobials for coliform mastitis except for serious cases and infections during the puerperal period. Others report a faster elimination of bacteria, increased survival, reduced inflammatory reaction, or decreased milk loss after parenteral treatment with fluoroquinolone antibiotics (Rantala et al., 2002; Poutrel et al., 2008). Erskine et al. (2002) showed 
a lower culling rate for severe cases of coliform mastitis when intramammary treatment with pirlimycin is supported by i.m. administration of ceftiofur over 5 consecutive days. A recent paper has shown that mild and moderate infections involving $E$. coli and Klebsiella pneumoniae have improved cure rates when using intramammary treatment with ceftiofur for 5 consecutive days (Schukken et al., 2011a). Escherichia coli-induced mastitis, particularly severe systemic cases, is associated with high cytokine concentrations (Bannerman, 2009), suggesting that a lower production of proinflammatory cytokines in the early phases of the inflammatory response may be beneficial to the affected dairy cow. The effect of steroidal anti-inflammatory drugs as an adjacent treatment to antibiotics has scarcely been investigated, however. Ziv et al. (1998) used a combination product of ampicillin, colistin, and dexamethasone in endotoxin-induced mastitis and observed an alleviation of clinical symptoms. Intramuscular dexamethasone treatment after intramammary challenge with $E$. coli reduced local clinical signs of inflammation and diminished inhibition of rumen amplitude during the acute phase of infection. Moreover, dexamethasone-treated cows showed diminished neutropenia and reduced milk loss at $14 \mathrm{~d}$ after the bacterial challenge (Lohuis et al., 1988). Treatment with isoflurpredone alone showed no effects on endotoxin induced mastitis in a more recent study, however (Wagner and Apley, 2004).

The anti-inflammatory effects of corticosteroids are mainly mediated through induction or repression of gene expression. The production of chemokines and cytokines is downregulated by inactivation of transcription factors, such as NF- $\kappa$ B or STAT6 (Zen et al., 2011). Due to this downregulation of transcription factors, several components of the inflammatory response, including the activation and recruitment of inflammatory cells (eosinophils, basophils, and lymphocytes), are prevented, such as natural killer cell activation and cytotoxicity and the release of inflammatory mediators (Schwiebert et al., 1996; Liu et al., 2001; Hsu et al., 2011). The production of cytokines is especially inhibited by corticosteroids on a broad range. In vitro-activated and dexamethasone-treated human blood leukocytes and peripheral lymphocytes from dexamethasone-treated calves displayed a substantial inhibition of IFN- $\gamma$, IL-1 $\beta$, IL-2, IL-3, IL-4, IL-8, and tumor necrosis factor- $\alpha$ on mRNA and protein (Menge and Dean-Nystrom, 2008; Liu et al., 2009; Spies et al., 2010; Maeda et al., 2011). Another study by Miljković et al. (2009) showed that methylprednisolone-treated rats challenged to develop encephalomyelitis had a reduced production of both IFN- $\gamma$ and IL-17 compared with PBS-treated controls. Though glucocorticoids inhibit cytokines on a broad range, they were shown to have a selective influence on frequencies of leukocyte subsets in claves. Dexamethasone treatment induced depletion of $\gamma \delta$ T-cell subsets, whereas the number of CD8+ and CD4+ aßT-cells was unchanged and the number of CD14+ cells increased in peripheral blood (Moiré et al., 2002; Menge and Dean-Nystrom, 2008)

Treatments combining an antimicrobial agent with a corticosteroid are popular in countries where these products are approved. The effects of the combination treatment on the local immune response are unclear. The objective of this study was to investigate the effect of prednisolone in combination with cefapirin on the dynamics of the early inflammatory response in an experimentally induced E. coli mastitis model. We focused on immediate effects of prednisolone on the inflammatory response during the first $48 \mathrm{~h}$ of the infection. The results of this study will help to better understand the influence of prednisolone on the dynamics of the early inflammatory response in the udder. This will open up possibilities to evaluate the potential benefit of a supportive treatment with corticosteroids in E. coli mastitis.

\section{MATERIALS AND METHODS}

\section{Animal Selection and Housing}

Six Holstein-Friesian cows were selected from the Cornell Teaching and Research Facility (Ithaca, NY) between August 2011 and January 2012. Animals were in their second to third lactation and between 77 to 188 DIM. All cows had SCC below $250,000 / \mathrm{mL}$ and no cases of clinical mastitis in the current lactation. Seven days before experimental infection, cows were transferred to the Cornell Large Animal Research and Teaching Unit (Ithaca, NY) and housed there until the end of the experiment. Experiments were conducted with 2 cows at a time. Cows were housed in pens on saw dust and milked twice daily at 12-h intervals using a milking system specifically designed with a quarter milker connected to 4 lactocorder devices (WMB-AG, Balgach, Switzerland) that measured quarter milk production and milk conductivity. General health status and rectal temperature were monitored at each milking and each sampling time. The cows were euthanized for tissue collection $24(\mathrm{n}=$ $3)$ and $48 \mathrm{~h}(\mathrm{n}=3)$ after infection. Animals were euthanized using a penetrating captive bolt gun followed by exsanguination. All procedures were approved by the Cornell Institutional Animal Care and Use Committee (project number: 2010-0078).

\section{Experimental Infection and Treatment Scheme}

Left front and both rear quarters were infected with 100 cfu of a fully characterized E. coli mastitis strain 
ECC-Z (Dogan et al., 2012). Bacteria were suspended in $1 \mathrm{~mL}$ of sterile PBS and administered via the teat canal. The right front quarter remained an uninfected control.

Four hours after bacterial challenge, 1 of the rear quarters was treated with the combination of $300 \mathrm{mg}$ of cefapirin and $20 \mathrm{mg}$ of prednisolone (MSD Animal Health, Boxmeer, the Netherlands). The other rear quarter was treated with $300 \mathrm{mg}$ of cefapirin (MSD Animal Health) only. The drugs were provided in a 10-mL oily suspension in an udder injector and administered through the teat canal. All further treatments were performed at the subsequent milking $(12,24$, and $36 \mathrm{~h}$ after challenge). Cows being euthanized after $24 \mathrm{~h}$ received 2 treatments in total and cows being euthanized after $48 \mathrm{~h}$ were treated 4 times in total.

\section{Sampling Procedures}

Prior to experimental infection, quarter milk samples and blood samples were obtained every $48 \mathrm{~h}$. Food intake, quarter milk production, and rectal temperature were recorded every day throughout the experiment. After bacterial challenge, blood and milk samples were obtained every $6 \mathrm{~h}$ and at the first treatment $(4 \mathrm{~h}$ postchallenge). Clinical and subclinical mastitis was evaluated by performing a California Mastitis Test (CMT) and measuring rectal temperature and udder swelling and sensitivity at each sampling. Milk samples were collected aseptically from each quarter and $100 \mu \mathrm{L}$ were immediately plated onto MacConkey agar and incubated at $37^{\circ} \mathrm{C}$ overnight for bacterial culture and identification. Gram-negative isolates were distinguished on MacConkey agar as pink colonies and frozen at $-80^{\circ} \mathrm{C}$ for molecular strain-typing by random amplification of polymorphic DNA (RAPD). Duplicate milk samples were obtained to measure cytokine levels and SCC. For cytokine analysis, milk was centrifuged at 20,000 $\times g$ and $4^{\circ} \mathrm{C}$ for $30 \mathrm{~min}$. The fat layer was removed and milk whey was collected and stored in aliquots of $200 \mu \mathrm{L}$ at $-20^{\circ} \mathrm{C}$ until ELISA was conducted.

Tissues $\left(\sim 25 \mathrm{~cm}^{3}\right)$ samples were taken immediately after euthanasia. The mammary gland was examined and tissue samples for histology and gene expression analyses were collected from all quarters. Tissue samples for RNA preparation were obtained from the midportion of each quarter and immediately snap frozen in liquid nitrogen. For histological analysis, tissue samples were obtained from 3 transverse locations: just above the gland sinus, the midportion of each glandular unit, and the dorsal portion of each glandular unit. For each of the 3 transverse locations, 3 parallel sagittal tissue samples were obtained; a lateral, a mid, and a medial section of each quarter, for a total of 9 sections per quarter. Tissue was immediately fixed in $10 \%$ neutral buffered formalin and processed for histology within $24 \mathrm{~h}$.

\section{Udder Swelling}

Swelling of udder quarters was assessed by measuring the distance between 2 dots applied with a waterproof permanent marker on each quarter at an approximate distance of $5 \mathrm{~cm}$ before challenge. The dots were placed on the caudal surface for the rear quarters and on the lateral side for front quarters. The initial distance was measured using a flexible measurement tape and recorded in centimeters at the time of challenge and subsequently at every sampling time.

\section{Udder Sensitivity}

Udder sensitivity was measured as tolerance to pressure applied with the Force Ten FDX Force Gage algometer (Wagner Instruments, Greenwich, CT). Measurements were performed as previously described by Fitzpatrick (2011). Briefly, pressure was applied with a concave probe head with a surface of $24.2 \mathrm{~cm}^{2}$ at the same spot where the measurement for swelling was performed. Three measurements were taken and the average pressure across these measurements was recorded. Pressure was applied until the operator of the algometer could not press any further or the animal showed an adverse reaction. The cows were trained on the use of the algometer before the start of the experiment, and in these prechallenge measurements a pressure of $10 \mathrm{~kg}$ was set as a general threshold for a nonsensitive udder. This pressure was tolerated without response by all cows after the initial few measurements.

\section{CMT and SCC}

A CMT was performed with milk from each quarter at every sampling time. An equal amount of milk was milked in a 4-quarter paddle and approximately the same amount of CMT reagent was added. The result was recorded immediately by rotating the paddle and scoring the texture and color of the mixture: $0=$ homogenous texture, light color; $0.5=$ slight thickening, reaction disappears in $10 \mathrm{~s} ; 1=$ distinct thickening, no gel formation, darker color; $2=$ thickens immediately, begins to gel, levels in the bottom of the cup, color between score 1 and 3; $3=$ gel is formed, surface elevates with a central peak above the mass, dark color. Higher scores display a higher density of somatic cells in the sample. Also, milk character was analyzed and presence of flakes and clots was recorded. Total SCC were determined per quarter by Fossomatic cell count- 
ing in an external milk analysis laboratory (Dairy One Cooperative Inc., Ithaca, NY).

\section{RAPD Strain-Typing}

Individual isolates from bacterial culture plates were recultured on lysogeny broth agar plates at $37^{\circ} \mathrm{C}$ for $12 \mathrm{~h}$. Colonies were removed from the plates using an inoculating loop. Subsequently, DNA was isolated from samples using QIAamp DNA Mini Kit (Qiagen, Valencia, CA) following the manufacturer's instructions. The PCR reaction was performed using the GoTaq Green Master Mix (Promega, Madison, WI). The primer used (5'-GCG ATC CCC A-3'; $20 \mu M$ ) was designed for RAPD to produce specific PCR products for gram-negative bacteria, and was shown to discriminate between several E. coli strains, causing transient and persistent mastitis (Dogan et al., 2006). The PCR products were evaluated using gel electrophoresis in a 1.5\% agarose gel at $60 \mathrm{~V}$ for $1.5 \mathrm{~h}$.

\section{Cytokine Analysis}

Enzyme-linked immunosorbent assays for bovine IL4, IL-1 $\beta$, IL-10, and IFN- $\gamma$ were performed according to the following protocol. Flat bottom 96-well plates (Thermo, Rockford, IL) were coated for $1.5 \mathrm{~h}$ at room temperature with $100 \mu \mathrm{L}$ of $0.05 M$ of carbonate buffer with a $\mathrm{pH}$ of 9.6 containing the respective dilution of the primary antibody: IL-4 (MCA2371; Serotec, Oxford, UK) and IL-1 $\beta$ (Thermo) at $2 \mu \mathrm{g} / \mathrm{mL}$, IFN- $\gamma$ at $1 \mu \mathrm{g} / \mathrm{mL}$ (MCA1783; Serotec), and IL-10 at $5 \mu \mathrm{g} /$ $\mathrm{mL}$ (MCA211; Serotec). Plates were washed 3 times with wash buffer (PBS containing 0.05\% Tween-20) and subsequently blocked with $2 \%$ fish skin gelatin (Sea Block buffer, Thermo) in PBS for $1 \mathrm{~h}$ at room temperature and washed 4 times in wash buffer. Subsequently, $100 \mu \mathrm{L}$ of the whey samples diluted $1: 5$ in PBS were added. Standard dilutions of known amounts of either recombinant bovine IL-4, IL-1 $\beta$ (Thermo), or IFN- $\gamma$ (Serotec) were assayed in parallel. Plates were incubated for $1.5 \mathrm{~h}$ at room temperature and subsequently washed 4 times with wash buffer. All wells were subsequently incubated with $100 \mu \mathrm{L}$ of the respective biotinylated secondary antibodies with the following concentrations: IL-4 at $5 \mu \mathrm{g} / \mathrm{mL}$ (MCA2372B; Serotec), IL-1 $\beta$ at $5 \mu \mathrm{g} / \mathrm{mL}$ (PBOIL1BBI; Thermo), IFN- $\gamma$ at $5 \mu \mathrm{g} / \mathrm{mL}$ (MCA1783B; Serotec), and IL-10 at $1 \mu \mathrm{g} /$ $\mathrm{mL}$ (MCA2111B; Serotec). Plates were incubated for $1.5 \mathrm{~h}$ at room temperature and subsequently washed 4 times with wash buffer. Then, streptavidin horseradish peroxidase (Serotec) was added to each well and plates were incubated for $1 \mathrm{~h}$ and protected from light at room temperature. After a final wash step, $100 \mu \mathrm{L}$ of $3,3^{\prime}, 5,5^{\prime}$-tetramethyl-benzidine (Sigma Aldrich, St. Louis, MO) was added and plates were incubated for 30 min and protected from light at room temperature. Finally the enzymatic reaction was stopped by adding $100 \mu \mathrm{L}$ of $2 \mathrm{~mol} / \mathrm{L}$ of sulfuric acid. Optical density (OD) was measured using a microplate reader (BioTek, Winooski, VT) at 450 and $568 \mathrm{~nm}$, and values were recorded as the difference between the 2 readings (delta OD). All samples, standards, and blanks were assayed in duplicate; variation coefficients were $\leq 15 \%$. Absolute concentrations of IL- 4 , IL- $1 \beta$, and IFN- $\gamma$ were calculated using delta OD values and the standard curve derived from the serial dilution of the recombinant proteins. Results for IL-10 are shown as delta OD values corrected by blank values.

\section{Histology}

Formalin-fixed tissue samples were embedded in paraffin, sectioned at $5 \mu \mathrm{m}$ thickness, and stained with hematoxylin and eosin for histological grading of inflammatory and tissue response. The sections were scored on a scale of 0 to 3 for the degree of PMNL infiltration of glandular parenchyma as follows: $0=$ absence of PMNL; $1=$ mild influx $(<5$ PMNL $) ; 2$ $=$ moderate influx $(5-10$ PMNL); $3=$ severe influx (>10 PMNL). Additionally, the degree of epithelial cell sloughing within the lumen of acini was scored as $0=$ $<25 \%$ of acini; $1=25$ to $50 \%$ of acini; $2=50$ to $75 \%$ of acini; and $3=>75 \%$ of acini showing sloughed epithelial cells. For sections taken from the mid and dorsal glandular parenchyma, each parameter was assessed in 10 random fields at $10 \times$ original magnification. For sections taken above the gland sinus, the degree of PMNL response was evaluated in 5 random ductal units at $10 \times$ original magnification. Epithelial cell sloughing was not assessed because it was inconsistent in this location. Mastitis severity was calculated as percent of the maximum possible sum of the scores (90 for mid and dorsal parenchyma, 30 for gland sinus) for the 2 categorical parameters across the 3 locations.

\section{Statistical Analyses}

Data were analyzed using SAS software Version 9.2 (SAS Institute Inc., Cary, NC). Descriptive statistics included frequency distribution and graphical analysis. A linear mixed model (PROC MIXED) was created with using individual cows as a random effect (RANDOM statement) and time within quarter as a repeated measures effect (REPEATED statement). The general model can be represented as 


$$
\begin{gathered}
\mathrm{Y}=\text { Intcpt }+ \text { chaltrt }+ \text { time point } \\
+ \text { cow }(\text { random })+\text { Re }
\end{gathered}
$$

where $\mathrm{Y}$ is the outcome variable of interest; Intcpt is the intercept; chaltrt is a categorical variable representing challenge untreated, challenged cefapirin treated, challenge cefapirin and prednisolone treated, and unchallenged control; time point is the time of observation relative to challenge; cow is random effect of the individual cow; and Re is a complex error term representing a correlation matrix for within-quarter correlations over time and an independent normally distributed error term. Interactions between time point and chaltrt in the model were significant.

Residual maximum likelihood procedures were used to compare least squares means of normally distributed data. Standard errors of the least squares means are presented in the graphical presentation of the results. Somatic cell counts were normalized by natural logtransformation (lnSCC) and postchallenge $\operatorname{lnSCC}$ of infected, treated quarters were expressed as percentage of $\operatorname{lnSCC}$ of infected, untreated quarters to display effects of treatments on SCC dynamics. The score of PMNL and epithelial sloughing in histological slides of udder tissue were analyzed with a linear mixed model (PROC MIXED) where cow was considered a random effect (RANDOM statement). As only 1 observation was present for each quarter (at the time euthanasia), no repeated effect was necessary. Residuals of all models were evaluated for normality and outliers. Statistical significance was set at $P \leq 0.05$.

\section{RESULTS}

\section{General Health Characteristics}

At approximately $18 \mathrm{~h}$ after challenge, all cows were clinically affected by the $E$. coli challenge as shown by swelling of the challenged and untreated quarter (Figure 1A) and a moderately elevated rectal temperature $\left(39.2 \pm 0.3^{\circ} \mathrm{C}\right)$. Cows did not show signs of systemic weakness or complete anorexia and continued to stand and walk in the provided housing facilities.

\section{Swelling and Udder Sensitivity}

Infected, untreated udder quarters showed swelling with an increase in the distance between the 2 marks on the quarter from $4.9 \pm 0.3 \mathrm{~cm}$ at time of challenge to $6.3 \pm 0.3 \mathrm{~cm}$ at $18 \mathrm{~h}$ and $5.9 \pm 0.3 \mathrm{~cm}$ at $24 \mathrm{~h}$ postchallenge. Treated quarters showed little to no increase in the distance between the marks on the rear quarters. Differences between treated and the infected,

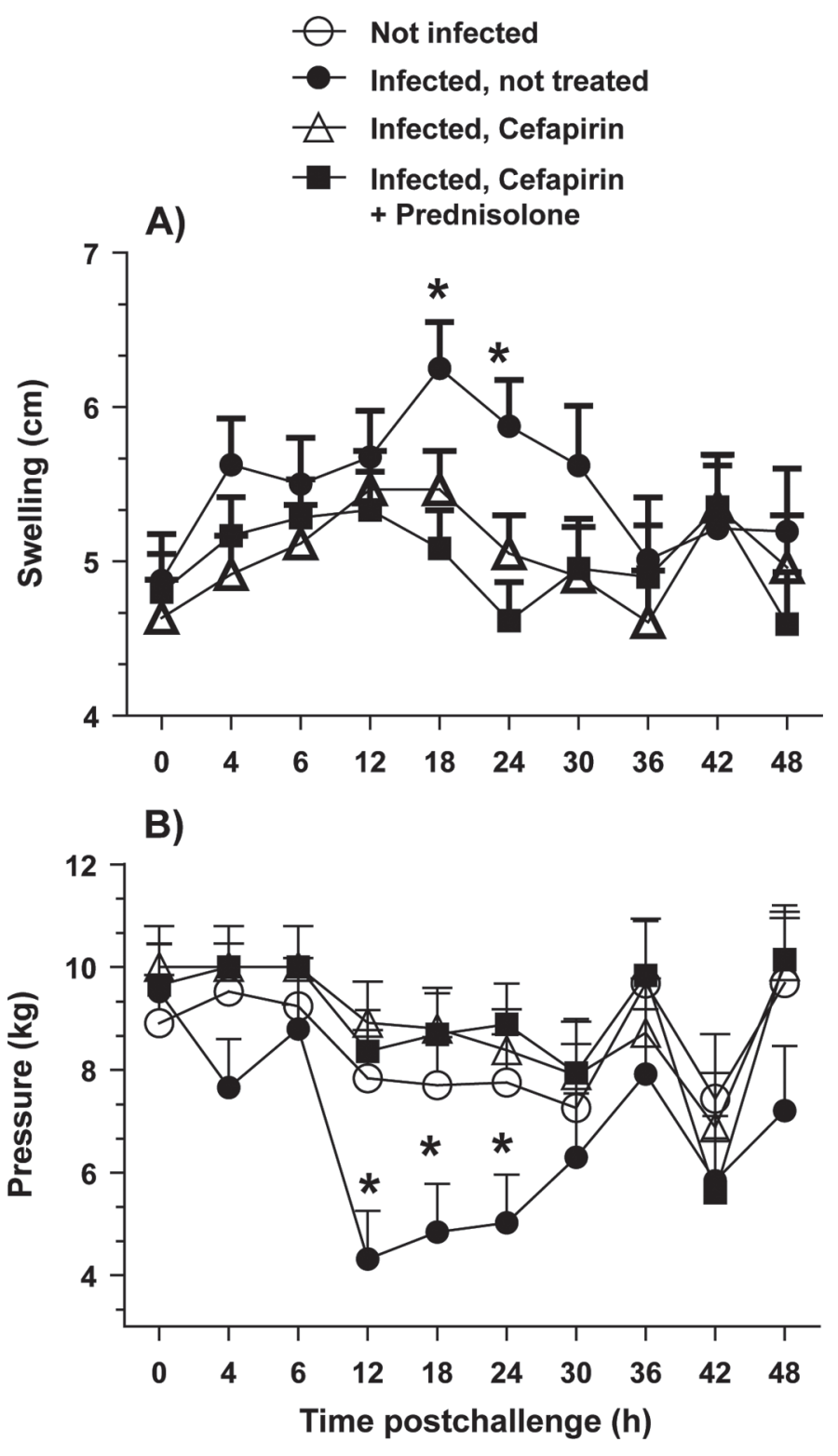

Figure 1. Six Holstein-Friesian cows were challenged with $100 \mathrm{cfu}$ of Escherichia coli in the left front and both rear quarters. Rear quarters were treated at $4,12,24$, and $36 \mathrm{~h}$ postchallenge with either $300 \mathrm{mg}$ of cefapirin only or $300 \mathrm{mg}$ of cefapirin and $20 \mathrm{mg}$ of prednisolone. (A) Swelling was measured as the distance (in centimeters) between 2 marks on the udder skin on the caudal surface of each hind quarter and the lateral surface of infected, untreated front quarters. *Infected, untreated quarters differed significantly from treated quarters at 18 and $24 \mathrm{~h}$. (B) Udder sensitivity is shown as the amount of pressure (in kilograms) tolerated on the caudal surface of hind quarters and the lateral surface of front quarters. *Infected, untreated quarters differ significantly from treated quarters and control quarters at 12 , 18, and $24 \mathrm{~h}$. Data are shown as LSM with SE for all animals (0-24 h: $\mathrm{n}=6 ; 30-48 \mathrm{~h}: \mathrm{n}=3)$. Uninfected quarters = open circles $(O)$; infected, untreated quarters $=$ filled circles $(\bullet)$; infected, cefapirin-treated $(300 \mathrm{mg})$ quarters $=$ open triangles $(\Delta)$; infected, cefapirin $(300 \mathrm{mg})$ plus prednisolone-treated $(20 \mathrm{mg})$ quarters $=$ filled squares $(\mathbf{\square})$. 
untreated quarters were statistically significant at 18 and 24 h (cefapirin only: $P=0.0314$ and 0.0237 ; cefapirin and prednisolone: $P=0.0017$ and 0.0008). Swelling decreased at $36 \mathrm{~h}$ postchallenge and showed a short peak at $42 \mathrm{~h}$ postchallenge in all measured quarters, which did not exceed the peak swelling in challenged, untreated quarters at 18 to $30 \mathrm{~h}$ (Figure 1A).

Udder sensitivity was measured as the amount of pressure tolerated on the udder quarters. In prechallenge measurements, a pressure of $10 \mathrm{~kg}$ was set as general threshold for a nonsensitive udder. All cows tolerated this amount of pressure without showing any response before challenge (data not shown). Postchallenge, uninfected quarters showed a slight decrease in pressure tolerance over the course of the experiment from $8.9 \pm 0.9 \mathrm{~kg}$ at the time of challenge and $9.5 \pm$ $0.9 \mathrm{~kg}$ at $4 \mathrm{~h}$ postchallenge to the lowest value of $7.2 \pm$ $1.2 \mathrm{~kg}$ at $30 \mathrm{~h}$ postinfection, and an increase in pressure tolerance to baseline values toward the end of the experiment again. Pressure tolerance in infected, untreated quarters dropped significantly at $12(P=0.0032)$, $18(P=0.0158)$, and $24 \mathrm{~h}(P=0.0212)$ postinfection compared with uninfected quarters. An application of $4.3 \pm 0.9 \mathrm{~kg}$ on infected quarters at $12 \mathrm{~h}$ postchallenge induced defense reactions by the cows, whereas, in uninfected control quarters, $7.8 \pm 0.9 \mathrm{~kg}$ was tolerated. Treated quarters did not show a reduction in pressure tolerance between 12 and $24 \mathrm{~h}$ after infection, and their sensitivity did not differ from uninfected quarters. No significant differences were observed between the 2 treatments at any time. At $42 \mathrm{~h}$ postchallenge, a de- crease in pressure tolerance was seen in all quarters. Uninfected and treated quarters showed prechallenge values again at $48 \mathrm{~h}$ postinfection, whereas infected, untreated quarters were still slightly lower in their pressure tolerance at that point in time (Figure 1B).

\section{Milk Production}

Quarter milk production was recorded from $6 \mathrm{~d}$ before experimental infection until the end of the experiment $(24 \mathrm{~h}$ postchallenge $\mathrm{n}=6 ; 48 \mathrm{~h}$ postchallenge $\mathrm{n}$ $=3$ ) for morning and evening milkings. Figure 2 shows the milk production during the whole trial for morning and evening milkings. As expected, front quarters show a lower production than hind quarters. Infection resulted in a statistically significant drop in production $24 \mathrm{~h}$ postchallenge compared with the last milking before challenge in all quarters (Figure 2; uninfected, untreated: $P=0.0124$; infected, untreated: $P=0.0004$; infected, cefapirin-treated: $P=0.0114$; infected, cefapirin and prednisolone-treated: $P=0.0003)$. No statistically significant differences were observed between any of the treatments and the control at any time.

\section{Bacterial Recovery and Cure Rates}

The E. coli strain used for experimental infection could be recovered from infected, untreated quarters of all cows. At $4 \mathrm{~h}$ postchallenge, 3 cows showed bacterial growth in challenged quarters. At $6 \mathrm{~h}$ postinfection, $E$. coli could be recovered from all challenged, untreated

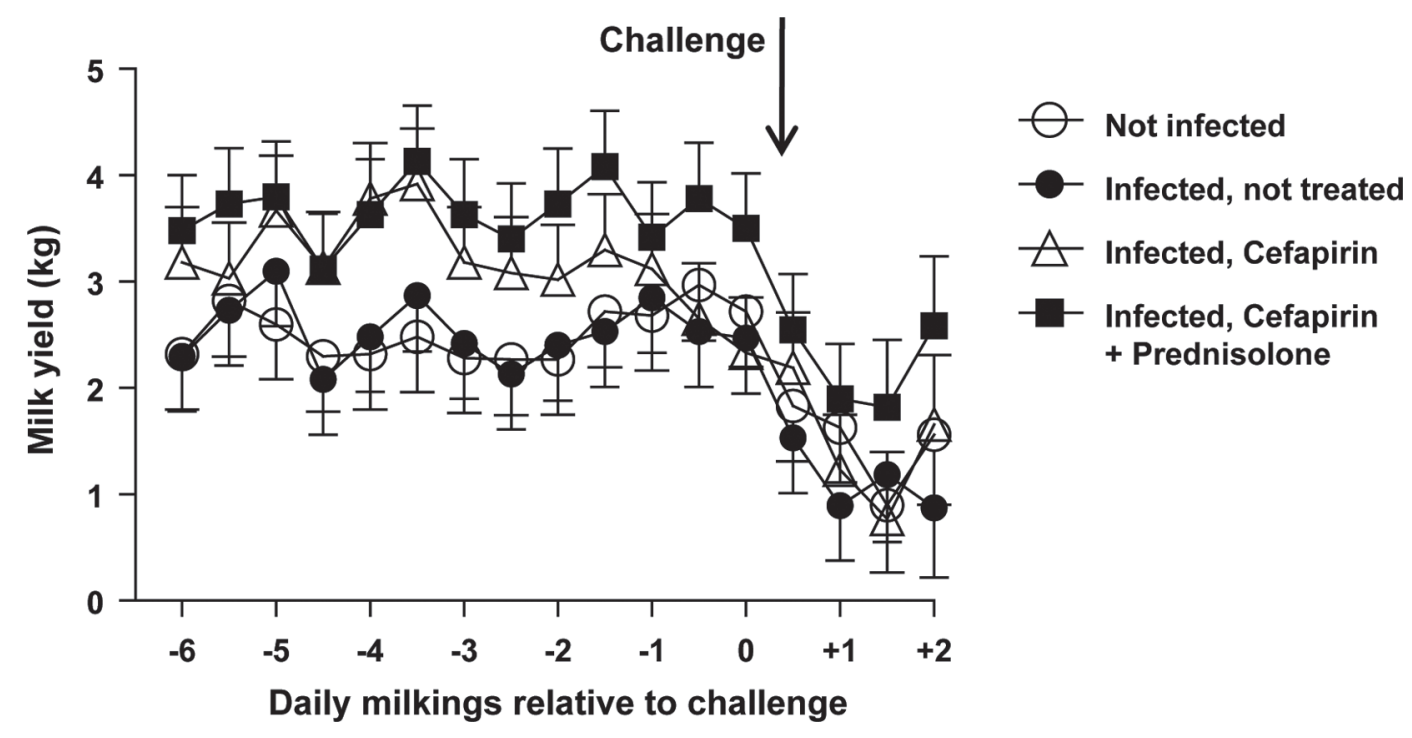

Figure 2. Cows were infected with 100 cfu of Escherichia coli in 3 quarters and treated at 4, 12, 24, and 36 h postchallenge. Quarter milk production was recorded for morning and evening milking over $6 \mathrm{~d}$ before challenge and for the following $2(\mathrm{n}=6)$ or $4(\mathrm{n}=3)$ milkings postchallenge. Quarter milk yield (in kilograms) at a.m. and p.m. milkings before and after challenge is recorded as LSM with SE. Uninfected quarters $=$ open circles $(\bigcirc)$; infected, untreated quarters $=$ filled circles $(\bullet)$; infected, cefapirin-treated $(300 \mathrm{mg})$ quarters $=$ open triangles $(\Delta)$; infected, cefapirin $(300 \mathrm{mg})$ plus prednisolone-treated $(20 \mathrm{mg})$ quarters = filled squares $(\mathbf{\square})$. 
quarters (Figure 3 ). The E. coli strain was verified by RAPD strain-typing. The challenge strain was at no time identified in unchallenged quarters. A high variation in colony forming units was observed between individual cows. Treatment with cefapirin inhibited growth in 3 cows immediately. Milk from 3 quarters treated with cefapirin, and 2 quarters treated with cefapirin and prednisolone, showed bacterial growth at a single sampling time post-treatment and colony forming units were low (Figure 3).

\section{CMT Scores and SCC}

The acquisition of CMT scores and the evaluation of milk characteristics in the course of the experiment showed a clear and significant distinction between treated and untreated quarters, as well as among the 2 treatments. Untreated, infected quarters had the highest CMT score starting at $18 \mathrm{~h}(3.0 \pm 0.21 ; P<$ $0.0001)$ postinfection and remaining on the same high level until the end of the experiment (Figure 4A). Milk characteristics in the infected, untreated quarters were abnormal, with clots and flakes. Treatment with cefapirin reduced CMT scores at $18 \mathrm{~h}$ postinfection significantly (to values of $2+; P<0.0001$ ) compared with infected, untreated quarters, and milk characteristics were less compromised compared with the untreated and challenged quarters (Figure 4A). The combination

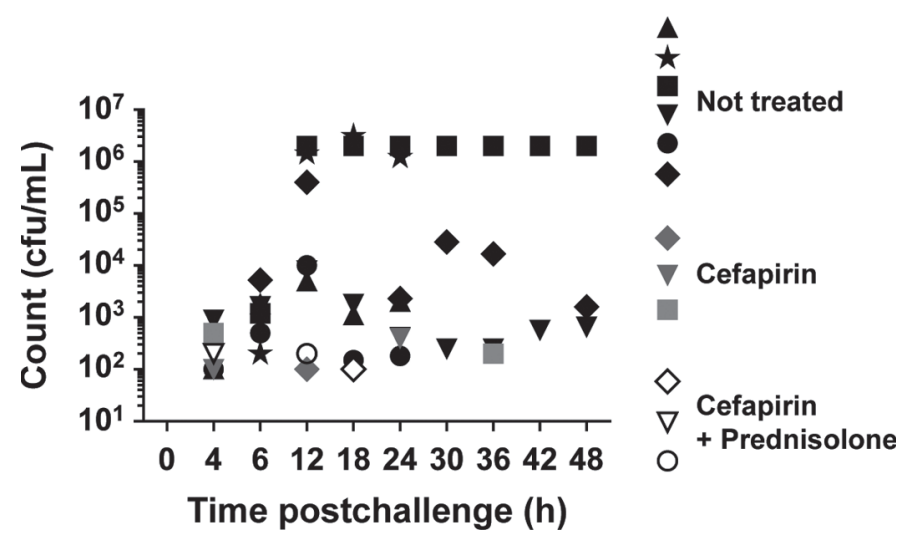

Figure 3. Cows were inoculated with $100 \mathrm{cfu}$ of Escherichia coli in 1 front and both rear quarters and treated at $4,12,24$, and $36 \mathrm{~h}$ postchallenge. The front quarters remained untreated (dark symbols) and the rear quarters were either treated with $300 \mathrm{mg}$ of cefapirin (gray symbols) or with the combination of $300 \mathrm{mg}$ of cefapirin and $20 \mathrm{mg}$ of prednisolone (open symbols). Sterile milk samples were taken at each sampling time and plated on MacConkey's agar. Colony-forming units were counted after $24 \mathrm{~h}$ of incubation at $37^{\circ} \mathrm{C}$; the E. coli strain was verified by random amplification of polymorphic DNA strain typing. Data are shown as colony forming units per milliliter of milk for individual animals and quarters for all sampling times postchallenge. When symbols are absent from the graph, no bacteria were found in the milk sample. of cefapirin with prednisolone further reduced CMT scores significantly $(P<0.0001)$ compared with quarters treated with cefapirin alone. Milk characteristics in cefapirin plus prednisolone-treated quarters were hardly compromised and resembled the milk of uninfected control quarters. Somatic cell counts of infected, untreated quarters started to increase at $12 \mathrm{~h}$ postchallenge and reached a peak at $18 \mathrm{~h}$ postinfection. Both treatments resulted in significantly $(P<0.0001)$ lower cell counts compared with challenged and untreated quarters at 18 to $42 \mathrm{~h}$ postinfection (Figure $4 \mathrm{~B}$ ). To display differences in SCC dynamics between the 2 treatments, $\operatorname{lnSCC}$ of treated quarters was shown as the percentage of $\operatorname{lnSCC}$ from infected, untreated quarters (Figures 4C and $4 \mathrm{D}$ ). The combination treatment with cefapririn and prednisolone resulted in a more pronounced resolution of high SCC between 18 and $42 \mathrm{~h}$ postchallenge compared with treatment with cefapirin alone, though the observed differences were not statistically significant.

\section{Cytokines in Milk Whey}

Only milk from infected, untreated quarters showed an increase in IFN- $\gamma$, IL-1 $\beta$, and IL-10 production. Levels of IL-1 $\beta$ increased at $12 \mathrm{~h}$ postchallenge and showed a 2-spiked secretion pattern with the first peak at $24 \mathrm{~h}$ with $0.13 \pm 0.02 \mathrm{ng} / \mathrm{mL}$, a low at $36 \mathrm{~h}(0.05 \pm 0.03 \mathrm{ng} /$ $\mathrm{mL})$, and the second peak at $42 \mathrm{~h}$ postinfection (0.16 $\pm 0.03 \mathrm{ng} / \mathrm{mL}$; Figure 5). Interferon gamma showed a first increase at $24 \mathrm{~h}$ postinfection and reached peak production at $36 \mathrm{~h}$ postinfection $(3.8 \pm 0.45 \mathrm{ng} / \mathrm{mL}$; Figure 5). Increased levels of IL-10 could be measured at $18 \mathrm{~h}$ postinfection, remained at the same high level until $36 \mathrm{~h}$ postchallenge, and dropped again to lower, but still measurable, levels at the end of the experiment (Figure 5). All previously mentioned cytokines were either undetectable in milk from treated quarters and uninfected quarters or showed very low concentrations.

Interleukin-4 showed measurable concentrations in the milk of treated quarters. Infected, untreated quarters showed the highest peak at $24 \mathrm{~h}$ postinfection $(0.23$ $\pm 0.02 \mathrm{ng} / \mathrm{mL}$ ) and a lower spike at $36 \mathrm{~h}$ postinfection $(0.11 \pm 0.03 \mathrm{ng} / \mathrm{mL})$. Cefapirin-treated quarters followed this pattern, with overall lower concentrations significant at $24 \mathrm{~h}$ postinfection $(0.10 \pm 0.02 \mathrm{ng} / \mathrm{mL} ; P$ $=0.0007)$. Quarters treated with the combination of cefapirin and prednisolone showed a lower increase, with a significantly lower concentration at $24 \mathrm{~h}$ postinfection $(0.02 \pm 0.02 \mathrm{ng} / \mathrm{mL})$ compared with infected, untreated $(P<0.0001)$, as well as to cefapirin-only-treated quarters $(P=0.03$; Figure 5$)$. The cytokine secretion pattern in challenged, cefapirin plus prednisolone-treated quarters was similar to uninfected quarters. 


\section{$\vartheta$ Not infected \\ Infected, not treated \\ $\triangle$ Infected, Cefapirin \\ - Infected, Cefapirin \\ + Prednisolone}

A)
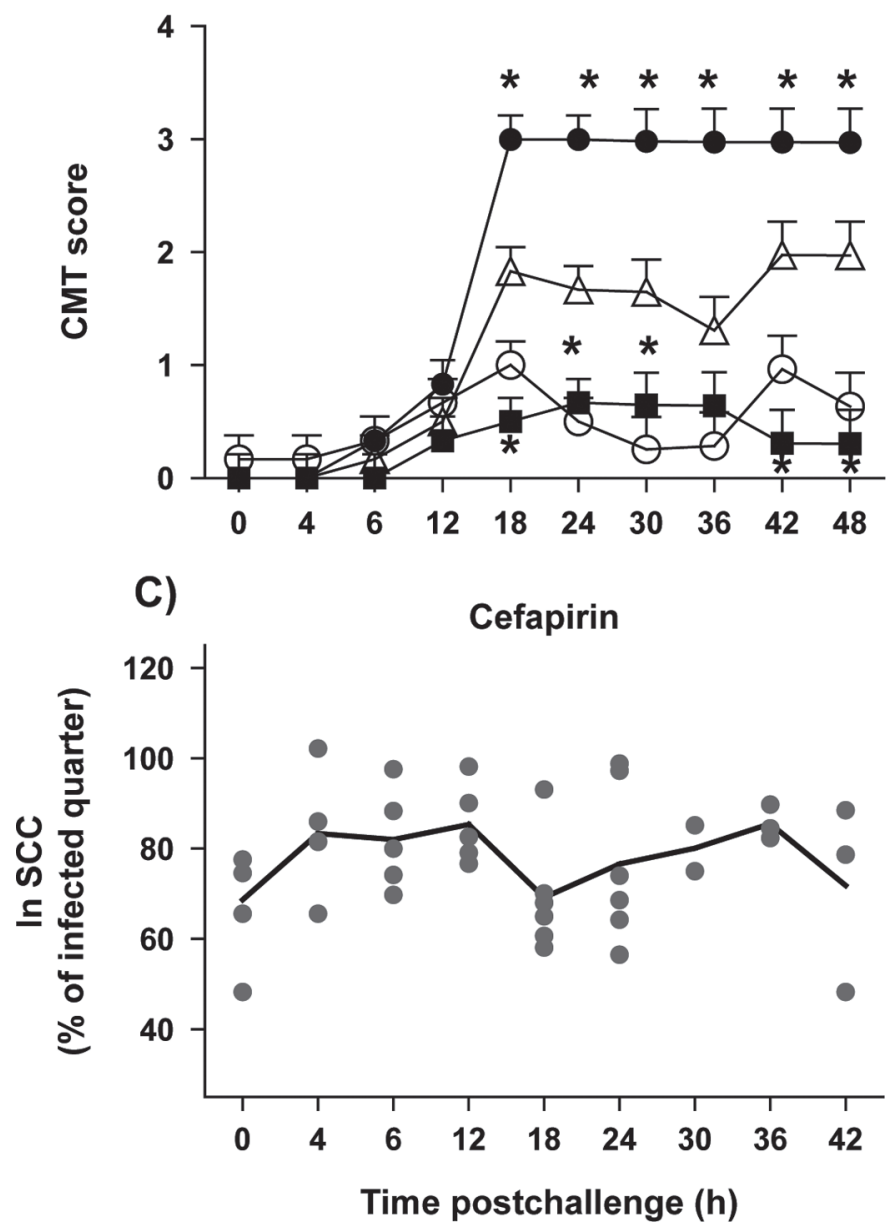

B)

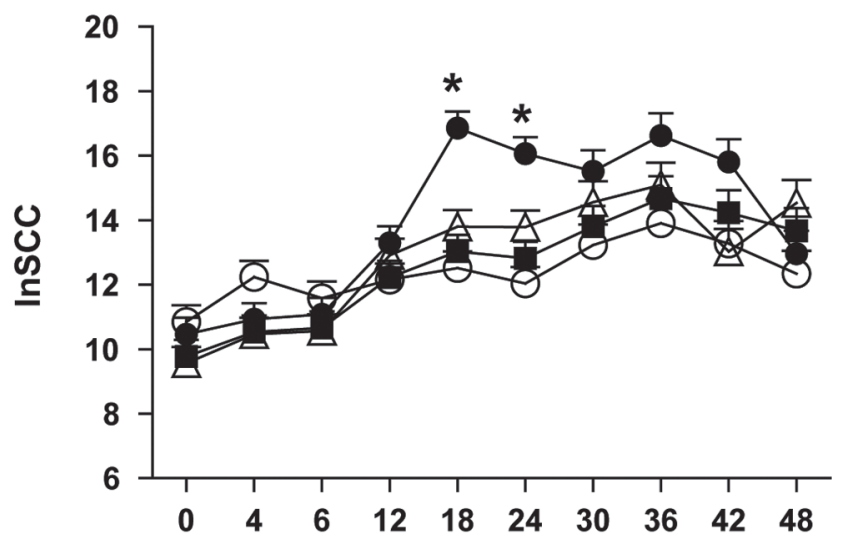

D)

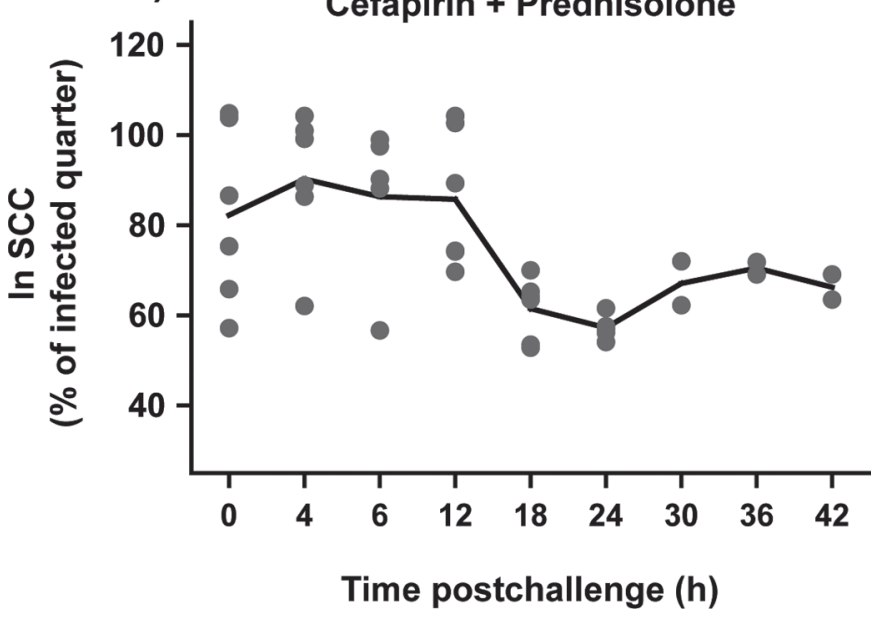

Figure 4. Six Holstein-Friesian cows were challenged with 100 cfu of Escherichia coli in left front and both rear quarters. Rear quarters were treated at 4,12,24, and $36 \mathrm{~h}$ postchallenge with either $300 \mathrm{mg}$ of cefapirin only or $300 \mathrm{mg}$ of cefapirin and $20 \mathrm{mg}$ of prednisolone. (A) A California Mastitis Test (CMT) was performed with milk from each quarter at each sampling point. The graph shows results as scores from 0 (negative) to 3 (gel formation, dark color and clots) as LSM with SE for all animals $(0-24 \mathrm{~h}: \mathrm{n}=6 ; 30-48 \mathrm{~h}: \mathrm{n}=3)$. *Infected, untreated quarters differed significantly from treated and control quarters at 18 to $48 \mathrm{~h}(P<0.0001)$. *Infected, cefapirin and prednisolone-treated quarters differed significantly from cefapirin-treated quarters at $18,24,30,42$, and $48 \mathrm{~h}(P<0.0001)$. (B) Somatic cell scores were obtained from each quarter at each sampling point and transformed to natural logarithms. Data are shown as LSM with SE for all animals $(0-24 \mathrm{~h}: \mathrm{n}=6 ; 30-48 \mathrm{~h}$ : $\mathrm{n}=3)$. Infected, untreated quarters differ significantly from control and treated quarters at 18 to $42 \mathrm{~h}(P<0.001)$. Uninfected quarters $=$ open circles $(\bigcirc)$; infected, untreated quarters = filled circles $(\mathbf{O})$; infected, cefapirin-treated $(300 \mathrm{mg})$ quarters $=$ open triangles $(\Delta)$; infected, cefapirin $(300 \mathrm{mg})$ plus prednisolone-treated $(20 \mathrm{mg})$ quarters = filled squares $(\boldsymbol{\nabla})$. An asterisk indicates significant differences between untreated and treated quarters and between treatments. (C) Development of the natural log of SCC in the course of the experiment in treated quarters. Data are shown as percentage of $\operatorname{lnSCC}$ of treated quarters from infected not treated quarters for cefapirin only. Data are shown as single values for each cow (dots) and means (line) (0-24 h: $\mathrm{n}=6 ; 30-48 \mathrm{~h}: \mathrm{n}=3$ ). (D) Data are shown as percentage of lnSCC of treated quarters from infected not treated quarters for the combination of cefapirin and prednisolone. Data are shown as single values for each cow (dots) and means (line; $0-24 \mathrm{~h}: \mathrm{n}=6 ; 30-48 \mathrm{~h}: \mathrm{n}=3)$.

\section{Udder Histology}

The degrees of PMNL infiltration and epithelial sloughing were not different between the 3 locations of sampling within each quarter. Additionally, no differences were seen in these parameters between tissue sections obtained 24 or $48 \mathrm{~h}$ postinoculation. All sections of inoculated, untreated quarters showed a significantly 


\section{- not infected \\ $\rightarrow$ infected, not treated \\ $\triangle$ infected, Cefapirin \\ - infected, Cefapirin + Prednisolone}
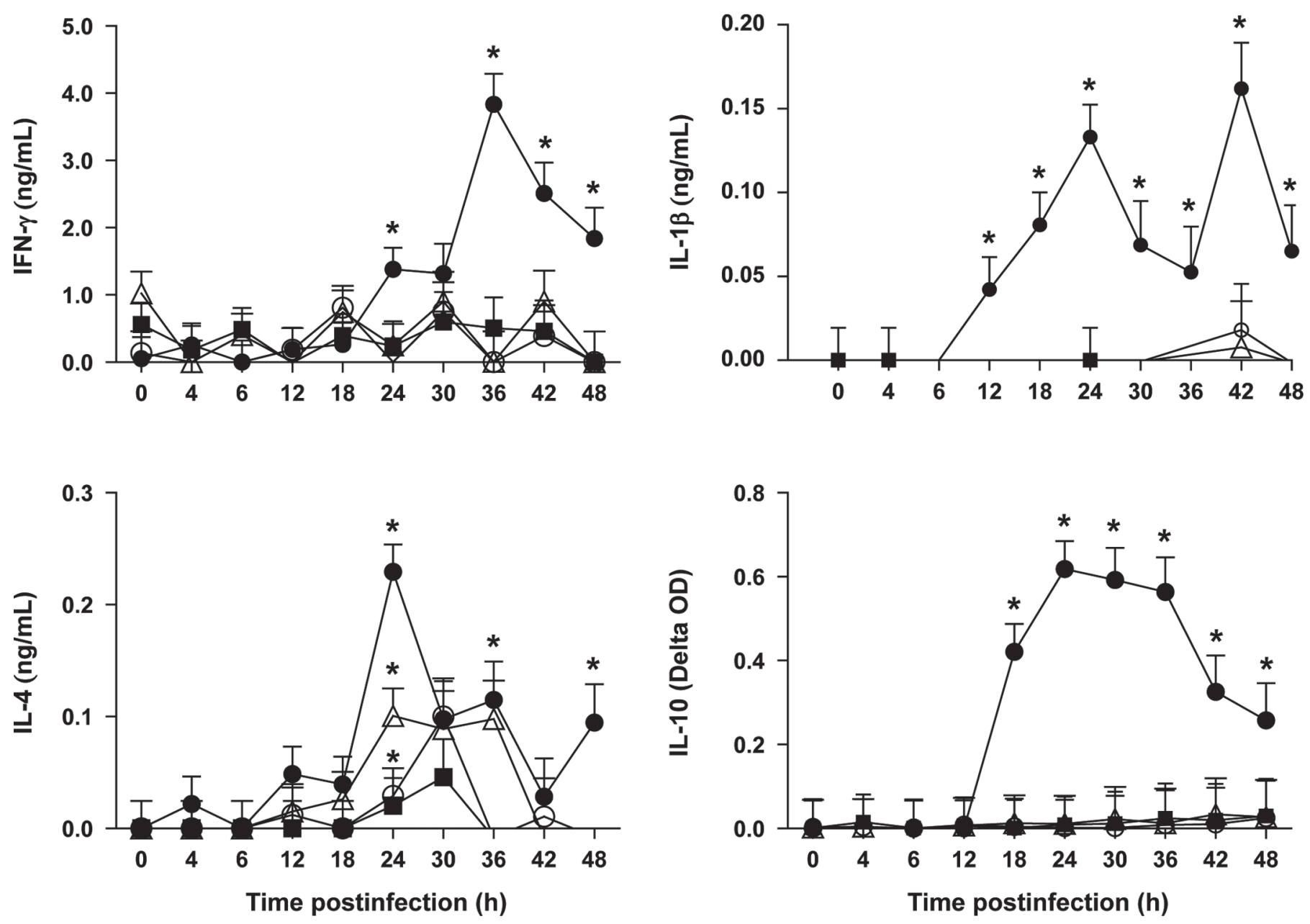

Figure 5. Six Holstein-Friesian cows were challenged with $100 \mathrm{cfu}$ of Escherichia coli in left front and both rear quarters. Rear quarters were treated at 4,12,24, and $36 \mathrm{~h}$ postchallenge with either $300 \mathrm{mg}$ of cefapirin only or $300 \mathrm{mg}$ of cefapirin and $20 \mathrm{mg}$ of prednisolone. Cytokine levels were determined by ELISA. Data are shown as LSM with SE for all animals $(0-24 \mathrm{~h}: \mathrm{n}=6 ; 30-48 \mathrm{~h}: \mathrm{n}=3)$. Uninfected quarters $=$ open circles $(\bigcirc)$; infected, untreated quarters $=$ filled circles $(\mathbf{O})$; infected, cefapirin-treated $(300 \mathrm{mg})$ quarters $=$ open triangles $(\Delta)$; infected, cefapirin $(300 \mathrm{mg})$ plus prednisolone-treated $(20 \mathrm{mg})$ quarters $=$ filled squares $(\boldsymbol{\square})$. An asterisk indicates statistically significant differences at $P<0.05$. $\mathrm{OD}=$ optical density.

higher degree of PMNL response (Figure 6). Treatment with cefapirin resulted in a significantly lower degree of PMNL infiltration compared with inoculated, untreated quarters $(P<0.0001)$, and PMNL density remained higher compared with uninoculated control quarters. Quarters treated with cefapirin in combination with prednisolone had a significantly reduced PMNL response compared with quarters treated with cefapirin alone $(P=0.0305)$, and the degree of PMNL response was not significantly different from uninfected control quarters. Moderate epithelial sloughing was present in inoculated quarters. The degree of epithelial sloughing was significantly greater in inoculated than uninoculated quarters irrespective of treatment $(P=0.0023)$.

\section{DISCUSSION}

The decision on whether and how to treat E. coli mastitis depends on the severity of the case, which is determined to a large extent by the hosts' individual 
PMN density in tissue 24 and $48 \mathrm{~h}$ postchallenge
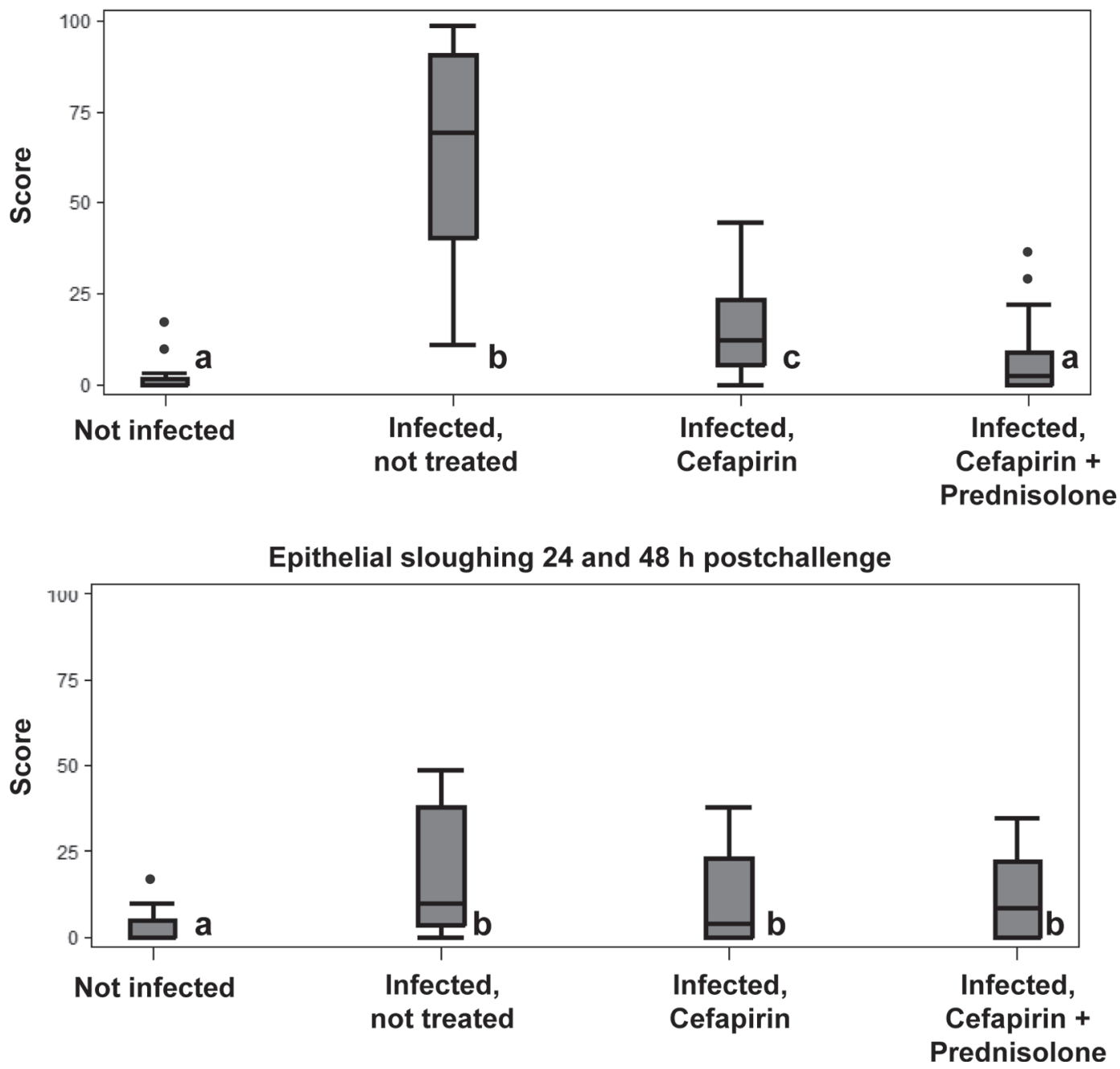

Figure 6. Mammary gland tissue of all 6 cows was harvested at $24 \mathrm{~h}(\mathrm{n}=3)$ or $48 \mathrm{~h}(\mathrm{n}=3)$ postinoculation with 100 cfu of Escherichia coli in 3 quarters. Left front quarters were left untreated and rear quarters were either treated with $300 \mathrm{mg}$ of cefapirin or a combination of $300 \mathrm{mg}$ of cefapirin and $20 \mathrm{mg}$ of prednisolone at 4,12,24, and $36 \mathrm{~h}$. Formalin-fixed and paraffin-embedded sections were stained with hematoxylin and eosin and 10 random $10 \times$ power fields were scored for the degree of PMNL infiltration $[0=$ absence of PMN; $1=$ mild influx $(<5$ PMN); $2=$ moderate influx (5-10 PMN); $3=$ severe influx ( $>10 \mathrm{PMN})]$ and epithelial cell sloughing $(0=<25 \%$ of acini; $1=25-50 \%$ of acini; $2=50-75 \%$ of acini; and $3=>75 \%$ of acini showing sloughed epithelia). Data are shown as the percentage of the maximum possible sum of the scores for each parameter for all cows in box and whisker plots displaying median and interquartile range; dots represent outliers. Different letters (a-c) indicate significance.

immune response rather than by the pathogen itself (Burvenich et al., 2003; Constable et al., 2009) and to a lesser extent on bacterial characteristics (Dogan et al., 2006). To facilitate within-cow comparisons of different treatments, we set up a mastitis model where we infected 3 quarters and treated 2 of the challenged quarters with either cefapirin alone or in combination with prednisolone. The conditions of the experimental infection were chosen such that we obtained a moderate clinical response. These challenge conditions included animals in midlactation and a low challenge dose with a strain of $E$. coli known to invoke a nonsevere, more persistent IMI and, subsequently, a moderate immune response (Dogan et al., 2012). We observed a moderate clinical mastitis in challenged, untreated quarters with limited effect on the remaining quarters, as evidenced by a virtually absent response in unchallenged control quarters. Despite the nonsevere response, the secretion profile of IL-1 $\beta$, IFN- $\gamma$, IL-4, and IL-10 in milk whey of untreated, challenged quarters was similar to previously reported E. coli IMI (Bannerman et al., 2004).

The MIC of cefapirin for E. coli ECC-Z in vitro was $16 \mathrm{mg} / \mathrm{L}$ (data not shown), which is within the range of the MIC determined for other E. coli isolates from 
cows with clinical mastitis (Constable and Morin, 2002; Guérin-Faublée et al., 2003). Cefapirin treatment resulted in a rapid inhibition of bacterial growth with the first treatment (Figure 3). The mastitis model used in the study with a bacterial challenge on 3 quarters in each animal made the early infection intervention a necessary compromise to prevent systemic disease and to enable investigating local effects of the treatments. This rapid bacterial kill likely occurred earlier than what may be expected to occur under natural infection circumstances on commercial dairy farms. At the time of initiation of treatment, no increased SCC or CMT score (Figures $4 \mathrm{~A}$ and $4 \mathrm{~B}$ ) and no decreased tolerance to pressure or swelling visible were noted (Figures 1A and $1 \mathrm{~B}$ ). The experimental results of this study therefore provide insight into the dynamics of early, local inflammatory response and the effect of intervention with antibiotics in combination with corticosteroids. However, these insights into the patho-biology of inflammatory response after challenge may not accurately reflect the actual outcome of treatment under field conditions of coliform mastitis on commercial dairy farms. Quarters treated with cefapirin alone showed reduced swelling and increased tolerance to pressure (Figures $1 \mathrm{~A}$ and $1 \mathrm{~B})$. The temporary peak of swelling and the reduction in tolerance to pressure at $42 \mathrm{~h}$ postchallenge in all measured quarters coincided with the peak in IL-1 $\beta$ secretion in milk whey of challenged, untreated quarters (Figures 1A, 1B, and 5) and can be seen as an endocrine, proinflammatory effect of the cytokine at its peak concentration (Goff et al., 1992). Levels of IL$1 \beta$, IFN- $\gamma$, and IL-10 remained at low or undetectable levels after treatment with cefapirin alone or cefapirin with prednisolone (Figure 5). This suggests either a lack of bacterial activation of pattern recognition receptors due to the early antibiotic treatment or a potential immune-modulatory property of the antibiotic itself. Brooks et al. (2005) showed a conjugation of cefaloridine with IFN- $\gamma$, which potently inhibits biological activity of the cytokine by decreasing the ability to induce CD54 expression on human lung epithelial cells. We did not measure biological activity of IFN- $\gamma$, but an interaction of cefapirin and the cytokine could be possible and may have impaired the detection (Figure 5). Despite a quick inhibition of bacterial growth, selective mechanisms of the inflammatory response must have been triggered in cefapirin-only-treated quarters, as seen by significantly elevated IL-4 levels, high CMT scores, and the significantly higher density of PMNL in mammary gland tissue 24 and $48 \mathrm{~h}$ after infection. The IL-4 secretion pattern in cefapirin-only-treated quarters is similar to untreated, infected quarters, but was significantly lower (Figure 5). For human T-cell lines from $\beta$-lactam-susceptible donors, it was shown that these antibiotics are able to skew the cytokine production toward a Th2-biased profile with an emphasis on IL-4 production (Brugnolo et al., 1999). It could be possible that cefapirin might have this effect on bovine immune cell populations in the mammary gland, which would explain the still existent IL-4 response though all other measured cytokines are below the detection limit in cefapirin-treated quarters. As in humans and mice, IL-4 is also favoring a Th2-driven, humoral adaptive immune response in bovine species, which is mainly characterized by antibody production (Estes et al., 1995). Additional treatment with prednisolone reduced production of IL-4 significantly, most likely through the inhibition of the STAT6 signaling pathway by corticosteroids (Bianchi et al., 2000), leading to a cytokine profile that was very similar to uninfected control quarters. This finding goes in line with results from Maeda et al. (2011), which showed a reduced mRNA expression of IL-4 in calf blood monocytes after dexamethasone treatment in vitro. The most consistent outcome across all cows was the significantly lower CMT score in quarters treated with prednisolone (Figure 4A) compared with cefapirin-only-treated and infected, untreated quarters. Similarly, SCC were more homogeneously reduced and density of PMNL in tissue was significantly lower compared with cefapirin-only-treated quarters (Figures $4 \mathrm{~A}-\mathrm{D}$ and Figure 6 ). To the best of our knowledge, the effect of prednisolone on PMNL migration in mastitis has not been studied so far. In humans, corticosteroids are known to inhibit IL-8, an important chemokine for PMNL (Liu et al., 2009); it is likely that the same applies for the bovine species. As a plethora of chemotactic mediators that govern PMNL migration exist, further investigations on the effect of prednisolone treatment on chemokine expression have to be performed to make specific conclusions.

Taken together, the results show a potent bacteriological cure of cefapirin alone in displaying inhibition of bacterial growth after $36 \mathrm{~h}$ in quarters treated with cefapirin alone, and after $18 \mathrm{~h}$ in quarters treated with cefapirin plus prednisolone (Figure 3). Furthermore, cefapirin treatment induced a distinct cytokine profile with an increase in IL-4 concentrations and downregulation of all other measured cytokines (Figure 5). Prednisolone further supported the effect of cefapirin by reducing the density of PMNL in milk and tissue, and thereby quickly restoring homeostasis in the udder. As a result, quarters challenged with $E$. coli and treated with cefapirin and prednisolone more quickly resembled uninfected control quarters. Prednisolone-treated quarters did not show a decline in milk production or a lack or delay in bacteriological cure going along with the observed reduction in PMNL density and CMT scores. Other observed differences were numerically smaller, 
and the low power of the trial due to the small number of animals may have prevented these smaller differences from becoming statistically significant. Particularly, the data of quarter swelling and quarter SCC show promising and relevant differences between the 2 treatment groups that were not statistically significant due to the relatively low power of this study. The observed differences in the present mastitis model between treated and control quarters and within the treated quarters are relevant and provide valid arguments for a further consideration of treatment of $E$. coli IMI with a combination therapy.

\section{ACKNOWLEDGMENTS}

This study was partially funded by Merck Animal Health (Summit, NJ).

\section{REFERENCES}

Bannerman, D. D. 2009. Pathogen-dependent induction of cytokines and other soluble inflammatory mediators during intramammary infection of dairy cows. J. Anim. Sci. 87(Suppl.):10-25.

Bannerman, D. D., M. J. Paape, J. W. Lee, X. Zhao, J. C. Hope, and P. Rainard. 2004. Escherichia coli and Staphylococcus aureus elicit differential innate immune responses following intramammary infection. Clin. Diagn. Lab. Immunol. 11:463-472.

Bianchi, M., C. Meng, and L. B. Ivashkiv. 2000. Inhibition of IL-2-induced Jak-STAT signaling by glucocorticoids. Proc. Natl. Acad. Sci. USA 97:9573-9578.

Brooks, B. M., C. A. Hart, and J. W. Coleman. 2005. Differential effects of beta-lactams on human IFN-gamma activity. J. Antimicrob. Chemother. 56:1122-1125.

Brugnolo, F., F. Annunziato, S. Sampognaro, P. Campi, M. Manfredi, A. Matucci, M. Blanca, S. Romagnani, E. Maggi, and P. Parronchi. 1999. Highly Th2-skewed cytokine profile of beta-lactam-specific $\mathrm{T}$ cells from nonatopic subjects with adverse drug reactions. J. Immunol. 163:1053-1059.

Burvenich, C., V. Van Merris, J. Mehrzad, A. Diez-Fraile, and L. Duchateau. 2003. Severity of E. coli mastitis is mainly determined by cow factors. Vet. Res. 34:521-564.

Constable, P. D., and D. E. Morin. 2002. Use of antimicrobial susceptibility testing of bacterial pathogens isolated from the milk of dairy cows with clinical mastitis to predict response to treatment with cephapirin and oxytetracycline. J. Am. Vet. Med. Assoc. 221:103-108.

Constable, P. D., S. Pyorala, and G. W. Smith. 2009. Guidelines for antimicrobial use in cattle. Pages $143-160$ in Guide to Antimicrobial Use in Animals. L. Guardabassi, L.B. Jensen, and H. Kruse, ed. Blackwell Publishing Ltd., Oxford, UK.

Dogan, B., S. Klaessig, M. Rishniw, R. A. Almeida, S. P. Oliver, K. Simpson, and Y. H. Schukken. 2006. Adherent and invasive Escherichia coli are associated with persistent bovine mastitis. Vet. Microbiol. 116:270-282.

Dogan, B., M. Rishniw, G. Bruant, J. Harel, Y. H. Schukken, and K. W. Simpson. 2012. Phylogroup and lpfA influence epithelial invasion by mastitis associated Escherichia coli. Vet. Microbiol. 159(1-2):163-170

Erskine, R. J., P. C. Bartlett, J. L. VanLente, and C. R. Phipps. 2002. Efficacy of systemic ceftiofur as a therapy for severe clinical mastitis in dairy cattle. J. Dairy Sci. 85:2571-2575.

Estes, D. M., A. Hirano, V. T. Heussler, D. A. Dobbelaere, and W. C. Brown. 1995. Expression and biological activities of bovine interleukin 4: Effects of recombinant bovine interleukin 4 on $\mathrm{T}$ cell proliferation and $\mathrm{B}$ cell differentiation and proliferation in vitro. Cell. Immunol. 163:268-279.

Fitzpatrick, C. 2011. Assessing and mediating pain in dairy cows with experimentally-induced clinical mastitis. Page 132 in Population Medicine. Vol. Master of Science. University of Guelph, Guelph, Canada.

Goff, J. P., Y. Naito, M. E. Kehrli Jr., P. Hayes, and M. Daley. 1992. Physiologic effects of administration of interleukin 1 beta in cows. Am. J. Vet. Res. 53:1983-1987.

Guérin-Faublée, V., G. Carret, and P. Houffschmitt. 2003. In vitro activity of 10 antimicrobial agents against bacteria isolated from cows with clinical mastitis. Vet. Rec. 152:466-471.

Hsu, A. K., H. Quach, T. Tai, H. M. Prince, S. J. Harrison, J. A. Trapani, M. J. Smyth, P. Neeson, and D. S. Ritchie. 2011. The immunostimulatory effect of lenalidomide on NK- cell function is profoundly inhibited by concurrent dexamethasone therapy. Blood 117:1605-1613.

Liu, M. C., D. Proud, L. M. Lichtenstein, W. C. Hubbard, B. S. Bochner, B. A. Stealey, L. Breslin, H. Xiao, L. R. Freidhoff, J. T. Schroeder, and R. P. Schleimer. 2001. Effects of prednisone on the cellular responses and release of cytokines and mediators after segmental allergen challenge of asthmatic subjects. J. Allergy Clin. Immunol. 108:29-38.

Liu, Z., X. Yuan, Y. Luo, Y. He, Y. Jiang, Z. K. Chen, and E. Sun. 2009. Evaluating the effects of immunosuppressants on human immunity using cytokine profiles of whole blood. Cytokine 45:141147.

Lohuis, J. A., W. Van Leeuwen, J. H. Verheijden, A. S. Van Miert, and A. Brand. 1988. Effect of dexamethasone on experimental Escherichia coli mastitis in the cow. J. Dairy Sci. 71:2782-2789.

Maeda, Y., R. Tanaka, H. Ohtsuka, K. Matsuda, T. Tanabe, and M. Oikawa. 2011. Comparison of the immunosuppressive effects of dexamethasone, flunixin meglumine and meloxicam on the in vitro response of calf peripheral blood mononuclear cells. J. Vet. Med. Sci. 73:957-960.

Menge, C., and E. A. Dean-Nystrom. 2008. Dexamethasone depletes gammadelta $\mathrm{T}$ cells and alters the activation state and responsiveness of bovine peripheral blood lymphocyte subpopulations. J. Dairy Sci. 91:2284-2298.

Miljković, Z., M. Momcilovic, D. Miljkovic, and M. Mostarica-Stojkovic. 2009. Methylprednisolone inhibits IFN-gamma and IL-17 expression and production by cells infiltrating central nervous system in experimental autoimmune encephalomyelitis. J. Neuroinflammation $6: 37$.

Moiré, N., O. Roy, and L. Gardey. 2002. Effects of dexamethasone on distribution and function of peripheral mononuclear blood cells in pneumonic calves. Vet. Immunol. Immunopathol. 87:459-466.

Poutrel, B., M. R. Stegemann, O. Roy, F. Pothier, N. Tilt, and M. Payne-Johnson. 2008. Evaluation of the efficacy of systemic danofloxacin in the treatment of induced acute Escherichia coli bovine mastitis. J. Dairy Res. 75:310-318.

Pyörälä, S., L. Kaartinen, H. Kack, and V. Rainio. 1994. Efficacy of two therapy regimens for treatment of experimentally induced Escherichia coli mastitis in cows. J. Dairy Sci. 77:453-461.

Rantala, M., L. Kaartinen, E. Valimaki, M. Stryrman, M. Hiekkaranta, A. Niemi, L. Saari, and S. Pyorala. 2002. Efficacy and pharmacokinetics of enrofloxacin and flunixin meglumine for treatment of cows with experimentally induced Escherichia coli mastitis. J. Vet. Pharmacol. Ther. 25:251-258.

Schukken, Y. H., G. J. Bennett, M. J. Zurakowski, H. L. Sharkey, B. J. Rauch, M. J. Thomas, B. Ceglowski, R. L. Saltman, N. Belomestnykh, and R. N. Zadoks. 2011a. Randomized clinical trial to evaluate the efficacy of a 5-day ceftiofur hydrochloride intramammary treatment on nonsevere gram-negative clinical mastitis. J. Dairy Sci. 94:6203-6215.

Schukken, Y. H., J. Gunther, J. Fitzpatrick, M. C. Fontaine, L. Goetze, O. Holst, J. Leigh, W. Petzl, H. J. Schuberth, A. Sipka, D. G. Smith, R. Quesnell, J. Watts, R. Yancey, H. Zerbe, A. Gurjar, R. N. Zadoks, and H. M. Seyfert. 2011b. Host-response patterns of intramammary infections in dairy cows. Vet. Immunol. Immunopathol. 144:270-289. 
Schwiebert, L. M., L. A. Beck, C. Stellato, C. A. Bickel, B. S. Bochner, and R. P. Schleimer. 1996. Glucocorticosteroid inhibition of cytokine production: relevance to antiallergic actions. J. Allergy Clin. Immunol. 97:143-152.

Spies, C. M., T. Gaber, M. Hahne, L. Naumann, R. Tripmacher, S. Schellmann, C. Stahn, G. R. Burmester, A. Radbruch, and F. Buttgereit. 2010. Rimexolone inhibits proliferation, cytokine expression and signal transduction of human CD4+ T-cells. Immunol. Lett. 131:24-32.

Suojala, L., H. Simojoki, K. Mustonen, L. Kaartinen, and S. Pyorala. 2010. Efficacy of enrofloxacin in the treatment of naturally occurring acute clinical Escherichia coli mastitis. J. Dairy Sci. 93:1960-1969
Wagner, S. A., and M. D. Apley. 2004. Effects of two anti-inflammatory drugs on physiologic variables and milk production in cows with endotoxin-induced mastitis. Am. J. Vet. Res. 65:64-68.

Zen, M., M. Canova, C. Campana, S. Bettio, L. Nalotto, M. Rampudda, R. Ramonda, L. Iaccarino, and A. Doria. 2011. The kaleidoscope of glucorticoid effects on immune system. Autoimmun. Rev. 10:305-310.

Ziv, G., M. Shem-Tov, and F. Ascher. 1998. Combined effect of ampicillin, colistin and dexamethasone administered intramuscularly to dairy cows on the clinico-pathological course of E. coli-endotoxin mastitis. Vet. Res. 29:89-98. 